\title{
Analisis Pengaruh Kualitas Pelayanan terhadap Kepuasan Tinggi dan Rendah Nasabah di Bank Syari'ah Mandiri Cabang Salatiga
}

Wiyanto

Fakultas Ekonomi dan Bisnis Islam IAIN Salatiga

Email: wiyantopegasus@ymail.com

\section{Abstract}

The purpose of this study was to test the effect of a variable quality of service with tangible, reliability, responsiveness, assurance and empathy on the high and low customer satisfaction at Syariah Mandiri Bank, Salatiga. The study used a sample of 150 students of the Faculty of Economics and Business Islam IAIN Salatiga. Multiple regression analysis was used to test hypotheses of the study after the classic assumption test and test validity and reliability.

The results showed that the variable of reliability, responsiveness, and empathy effect on the high and low customer satisfaction Syariah Mandiri Bank with the branch in Salatiga. Furthermore, the quality of service with these five indicators affect the high and low customer satisfaction Syariah Mandiri Bank, Salatiga together.

Keywords: quality of service, higher satisfaction, lower satisfaction

\section{Abstrak}

Tujuan penelitian ini adalah menguji pengaruh kualitas pelayanan dengan variabel tangible, reliability, responsiveness, assurance dan empathy pada kepuasan tinggi dan rendah nasabah di Bank Syariah Mandiri Cabang Salatiga. Penelitian menggunakan sampel sebesar 150 mahasiswa Fakultas Ekonomi dan Bisnis Islam IAIN Salatiga. Analisis regresi berganda digunakan untuk menguji hipotesis penelitian setelah dilakukan uji asumsi klasik dan uji validitas serta reliabilitas.

Hasil penelitian menunjukkan bahwa variabel reliability, responsiveness, dan empathy berpengaruh pada kepuasan tinggi dan rendah nasabah Bank Syariah Mandiri Cabang Salatiga secara parsial. Selanjutnya, kualitas pelayanan dengan lima indikator tersebut secara bersama-sama berpengaruh pada kepuasan tinggi dan rendah nasabah Bank Syariah Mandiri Cabang Salatiga.

Kata kunci: pengaruh, kualitas pelayanan, kepuasan tinggi, kepuasan rendah 


\section{Pendahuluan}

Menurut Direktur Utama Bank Mandiri, Sadikin, Bank Mandiri selalu melakukan pengembangan secara komprehensif di bidang pelayanan, karena cara bertransaksi nasabah telah mengalami pergeseran. Menurut Budi, hal tersebut membuat kami terus melakukan perbaikan secara menyeluruh dengan didasarkan pada kebutuhan nasabah. Pengembangan layanan tersebut menghasilkan kinerja yang baik. Dalam survei Bank Mandiri 2015 oleh Marketing Research Indonesia (MRI) dan Majalah Info Bank yang dilakukan di Jakarta, Bekasi, Depok, Tangerang, Bandung, Surabaya, Semarang dan Makassar, Bank Mandiri termasuk sepuluh bank terbaik dalam pelayanan Prima dan menjadi ke delapan kalinya secara berturut-turut. Bank Mandiri juga berhasil meraih predikat The Most Consistent Bank In Service Excellence untuk keenam kalinya dan penghargaan The Golden Thropy For Banking Service Excellence untuk yang keempat kalinya (Booklet Perbankan Indonesia, 2009).

Penghargaan ini membuktikan bahwa Bank Mandiri berhasil menjadikan service exellence sebagai bagian dari budaya perusahaan yang diterapkan secara konsisten dan berkelanjutan. Namun di tengah keberhasilan tersebut, Bank Mandiri pusat dan seluruh cabang masih saja memiliki banyak kendala diantaranya sistem jaringan online yang tidak stabil yang sering sekali mendapat komplain dari nasabah dan bagaimana cara memperluas jaringan nasabah dengan menyediakan kantor cabang yang memadai (Info Bank, 2015).

Sumardiningsih et. al. (2012) meneliti tentang pengaruh Banking Service Quality (BSQ) terhadap kepuasan nasabah Bank BPD di DIY. Sampel penelitian berjumlah 1536 responden. Variabel yang digunakan adalah dimensi SERVQUAL (Service Quality) maupun BSQ (Banking Service Quality). Hasil penelitian menunjukkan keenam dimensi $B S Q$ secara simultan berpengaruh positif dan signifikan terhadap kepuasan nasabah. Jika dilihat tiap dimensi maka pengaruh tertinggi berasal dari dimensi keterhandalan dan terendah dari dimensi akses serta portofolio jasa.

Sanistasya (2010) meneliti pengaruh kualitas pelayanan terhadap kepuasan nasabah dan loyalitas nasabah serta pengaruh kepuasan nasabah 
terhadap loyalitas nasabah. Berdasarkan hasil analisis jalur dapat diketahui bahwa (1) variabel kualitas pelayanan memiliki pengaruh signifikan terhadap variabel kepuasan nasabah, (2) variabel kualitas pelayanan berpengaruh signifikan terhadap variabel loyalitas nasabah, (3) variabel kepuasan nasabah tidak berpengaruh terhadap variabel loyalitas nasabah.

Sondakh (2014) menganalisis pengaruh kualitas layanan dan citra merek terhadap kepuasan nasabah dan dampaknya terhadap loyalitas nasabah pada nasabah Taplus Bank BNI Cabang Manado. Populasi dalam penelitian ini adalah nasabah Taplus yang berjumlah 1157 orang. Jumlah sampel 270 orang. Metode pengambilan data dilakukan dengan survei menggunakan kuesioner. Variabel penelitian ini menggunakan dimensi SERVQUAL (Service Quality). Hasil penelitian menunjukkan bahwa variabel kualitas pelayanan berpengaruh signifikan terhadap variabel kepuasan nasabah secara parsial. Variabel citra merek tidak berpengaruh terhadap variabel kepuasan nasabah secara parsial sementara variabel kepuasan nasabah berpengaruh signifikan terhadap variabel loyalitas nasabah.

Soffan (2013) meneliti tentang apakah variable assurance, reliability, responsivenees, tangible, dan emphaty berpengaruh terhadap kepuasan nasabah Bank BNI di Pasuruan. Sampel yang digunakan 100 responden. Hasil penelitian menunjukkan bahwa variabel assurance, reliability, responsiveness, tangible, dan emphaty secara parsial memiliki pengaruh yang signifikan terhadap kepuasan nasabah pengguna ATM BNI pada PT.Swadharma Sarana Informatika Pasuruan, variabel assurance, realibility, responsiveness, tangible, dan emphaty secara bersama-sama berpengaruh signifikan terhadap kepuasan nasabah pengguna ATM BNI pada PT. Swadharma Sarana Informatika Pasuruan, dan pengaruh responsiveness lebih besar dari assurance, relialibility, tangible, dan emphaty. 
Tabel 1

Hasil Penelitian Sebelumnya

\begin{tabular}{|c|c|c|c|}
\hline Nama Peneliti & Tahun & Judul & Hasil Penelitian \\
\hline $\begin{array}{l}\text { Sumardiningsih } \\
\text { et. al. }\end{array}$ & 2012 & $\begin{array}{l}\text { Pengaruh Dimensi Banking } \\
\text { Service Quality }(B S Q) \\
\text { terhadap Kepuasan Nasabah } \\
\text { Bank. }\end{array}$ & $\begin{array}{l}\text { BSQ berpengaruh positif terhadap } \\
\text { kepuasan nasabah }\end{array}$ \\
\hline Sanistasya & 2010 & $\begin{array}{l}\text { Pengaruh Kualitas Pelayanan } \\
\text { terhadap Kepuasan Nasabah } \\
\text { dan Loyalitas Nasabah } \\
\text { Tabungan Britama Pada PT. } \\
\text { Bank Rakyat Indonesia } \\
\text { (Persero) Tbk Cabang } \\
\text { Samarinda }\end{array}$ & $\begin{array}{l}\text { Variabel kualitas pelayanan } \\
\text { memiliki pengaruh signifikan } \\
\text { terhadap variabel kepuasan nasabah, } \\
\text { (2) variabel kualitas pelayanan } \\
\text { memiliki pengaruh signifikan } \\
\text { terhadap variabel loyalitas nasabah, } \\
\text { (3) variabel kepuasan nasabah tidak } \\
\text { memiliki pengaruh signifikan } \\
\text { terhadap variabel loyalitas nasabah. }\end{array}$ \\
\hline Sondakh & 2014 & $\begin{array}{l}\text { Kualitas Layanan, Citra } \\
\text { Merek Dan Pengaruhnya } \\
\text { terhadap Kepuasan Nasabah } \\
\text { Dan Loyalitas Nasabah } \\
\text { Tabungan (Studi Pada } \\
\text { Nasabah Taplus BNI Cabang } \\
\text { Manado) }\end{array}$ & $\begin{array}{l}\text { Variabel kualitas pelayanan } \\
\text { berpengaruh signifikan terhadap } \\
\text { kepuasan nasabah secara parsial. } \\
\text { Variabel citra merek tidak } \\
\text { berpengaruh terhadap kepuasan } \\
\text { nasabah secara parsial sementara } \\
\text { variabel kepuasan nasabah } \\
\text { berpengaruh signifikan terhadap } \\
\text { variabel loyalitas nasabah. }\end{array}$ \\
\hline Soffan & 2013 & $\begin{array}{l}\text { Kualitas Pelayanan } \\
\text { Pengelolaan ATM dan } \\
\text { Kepuasan Nasabah Bank BNI } \\
1946 \text { Pasuruan }\end{array}$ & $\begin{array}{l}\text { Variabel assurance, reliability, } \\
\text { responsiveness, tangible, dan } \\
\text { emphaty secara parsial memiliki } \\
\text { pengaruh yang signifikan terhadap } \\
\text { kepuasan nasabah pengguna ATM } \\
\text { BNI pada PT.Swadharma Sarana } \\
\text { Informatika Pasuruan, variabel } \\
\text { assurance, reliability, } \\
\text { responsiveness, tangible, dan } \\
\text { emphaty secara simultan memiliki } \\
\text { pengaruh yang signifikan terhadap } \\
\text { kepuasan nasabah pengguna ATM } \\
\text { BNI pada PT. Swadharma Sarana } \\
\text { Informatika Pasuruan, dan nilai } \\
\text { signifikansi variabel responsiveness } \\
\text { paling dominan diantara variabel } \\
\text { yang ada. }\end{array}$ \\
\hline
\end{tabular}

Berdasarkan hasil penelitian terdahulu di atas, dapat disimpulkan bahwa perbedaan penelitian ini dengan penelitian sebelumnya yaitu penelitian terdahulu (Sumardiningsih et. al., 2012, Soffan, 2013, Sanistasya, 2010, dan Sondakh, 2014) menggunakan satu ukuran kepuasan, sedangkan penelitian ini menggunakan ukuran kepuasan tinggi dan rendah dengan melakukan split sample. Tujuan split sample kepuasan tinggi dan kepuasan rendah untuk mengetahui konsistensi variabel yang mempengaruhi kepuasan. 


\section{Pembahasan}

Berdasarkan latar belakang masalah tersebut, maka rumusan masalah penelitian ini sebagai berikut:

1. Apakah tangible mempengaruhi kepuasan nasabah Bank Mandiri Syari'ah Cabang Salatiga?

2. Apakah reliability mempengaruhi kepuasan nasabah Bank Mandiri Syari'ah Cabang Salatiga?

3. Apakah responsiveness mempengaruhi kepuasan nasabah Bank Mandiri Syari'ah Cabang Salatiga?

4. Apakah assurance mempengaruhi kepuasan nasabah Bank Mandiri Syari'ah Cabang Salatiga?

5. Apakah emphaty mempengaruhi kepuasan nasabah Bank Mandiri Syari'ah Cabang Salatiga?

\section{Telaah pustaka}

Nasrul (2014) meneliti tentang Pengaruh Kualitas Pelayanan terhadap Kepuasan Nasabah pada PT. BPR Pembangunan Nagari Kantor Pusat Lubuk Basung. Sampel yang digunakan berjumlah 100 responden. Variabel penelitian ini menggunakan variabel kehandalan, daya tanggap, kepercayaan, kepedulian dan wujud fisik. Analisis data yang digunakan yaitu analisis regresi linear berganda. Hasil penelitian menunjukkan bahwa wujud fisik, kehandalan, daya tanggap, jaminan dan kepedulian berpengaruh signifikan terhadap kepuasan nasabah.

Sudarwati (2013) meneliti tentang Pengaruh Kualitas Pelayanan terhadap Kepuasan Nasabah Simpedes di Bank BRI Unit Baki. Penelitian menggunakan responden sebanyak 100 orang. Hasil menunjukkan bahwa kehandalan, daya tanggap, kepercayaan, kepedulian dan wujud fisik berpengaruh terhadap kepuasan nasabah Simpedes di Bank BRI Unit Baki.

Prasetyo (2011) meneliti tentang Analisis Pengaruh Kualitas Pelayanan terhadap Kepuasan Nasabah Bank Rakyat Indonesia (Studi Kasus pada Bank rakyat Indonesia Unit Sampangan Kantor Cabang Semarang). Populasi dalam penelitian ini adalah seluruh nasabah pada BRI Unit 
Sampangan, dengan sampel 94 responden. Variabel yang digunakan adalah variabel bukti langsung, kehandalan, daya tanggap, jaminan dan empati. Teknik analisis yang dipergunakan adalah regresi berganda. Hasil menunjukkan bahwa ada pengaruh positif antara bukti fisik, kehandalan, daya tanggap, jaminan dan empati terhadap kepuasan nasabah.

Guspul (2014) meneliti tentang Pengaruh Kualitas Layanan Kepercayaan terhadap Kepuasan Klien (Studi Kasus Klien Kospin Layanan Cabang Wonosobo). Sampel yang digunakan adalah 75 orang. Variabel yang digunakan yaitu variabel kualitas pelayanan, tangibles, reliability, responsiveness, assurance, empathy, keyakinan, dan kepuasan. Hasil penelitian ini menunjukan bahwa variabel kualitas pelayanan memiliki pengaruh dominan terhadap kepuasan nasabah Kospin Layanan Cabang Wonosobo.

Leksono (2013) yang berjudul Analisis Pengaruh Kualitas Pelayanan terhadap Kepuasan Nasabah Pengguna Kartu BPD Card Bank Jateng Cabang Utama Semarang. Penelitian ini mengukur kualitas pelayanan yang diproyeksikan dalam lima komponen, yaitu sikap pelanggan, tanggapan penyedia jasa dalam menanggapi keluhan pelanggan, jasa pembayaran, fasilitas tambahan, dan ketepatan waktu pelayanan. Hasil penelitian menyatakan bahwa sikap pelanggan dan tanggapan penyedia jasa dalam menghadapi keluhan pelanggan memuaskan pelanggan, sedangkan kualitas pelayanan yang belum memuaskan pelanggan adalah jasa pembayaran, fasilitas tambahan dan ketetapan waktu.

\section{Kualitas pelayanan}

Menurut Kotler (2002) pelayanan adalah setiap tindakan atau kegiatan yang dapat ditawarkan oleh suatu pihak kepada pihak lain, yang pada dasarnya tidak berwujud dan tidak mengakibatkan kepemilikan apapun. Pelayanan merupakan perilaku produsen dalam rangka memenuhi kebutuhan dan keinginan konsumen demi tercapainya kepuasan pada konsumen dan pembelian ulang.

Menurut Tjiptono dan Chandra (2011) kualitas pelayanan dapat diketahui dengan cara membandingkan persepsi para konsumen atas pelayanan yang mereka terima atau peroleh dengan pelayanan yang sesung- 
guhnya mereka harapkan atau inginkan terhadap atribut-atribut pelayanan perusahaan. Jika jasa yang diterima atau dirasakan (perceied service) sesuai dengan yang diharapkan, maka kualitas pelayanan dipersepsikan baik dan memuaskan jika jasa yang diterima melampaui harapan konsumen, maka kualitas pelayanan dipersepsikan sangat baik dan berkualitas. Sebaliknya jika jasa yang diterima lebih rendah dari pada yang diharapkan, maka kualitas pelayanan dipersepsikan buruk.

\section{Kepuasan pelanggan}

Kotler (2002) menyatakan bahwa kepuasan adalah perasaan senang atau kecewa seseorang yang berasal dari perbandingan kesannya terhadap kinerja atau hasil suatu produk dan harapan-harapannya. Jika kinerja berada di bawah harapan, pelanggan tidak puas. Hal ini dapat membawa dampak negatif bagi perusahaan yaitu dapat menurunkan jumlah pelanggan dan menyebabkan pelanggan tidak tertarik lagi menggunakan jasa perusahaan sehingga akan menurunkan laba perusahaan.

Menurut Engel yang dikutip Abdullah (2012) kepuasan pelanggan merupakan evaluasi purna beli di mana alternatif yang dipilih sekurangkurangnya sama atau melampaui harapan pelanggan, sedangkan ketidakpuasan timbul apabila hasil tidak memenuhi harapan. Penilaian kepuasan pelanggan mempunyai tiga bentuk yang berbeda, yaitu:

1. Positive disconfirmation, di mana kinerja lebih baik dari harapan.

2. Simple confirmation, di mana kinerja sama dengan harapan.

3. Negative disconfirmation, di mana kinerja lebih buruk dari harapan.

Kepuasan pelanggan tidak berarti memberikan kepada pelanggan apa yang kita perkirakan disukai oleh pelanggan. Namun kita harus memberikan apa yang sebenarnya mereka inginkan, kapan diperlukan dan dengan cara apa mereka memperolahnya. Menurut Zeithaml, Valarie A. dan Bitner (2003) tahapan-tahapan membentuk kepuasan pelanggan, yaitu:

a) Menemukan kebutuhan pokok, yang merupakan "the basic needs of costumers".

b) Mencari tahu apa yang sebenarnya menjadi harapan pelanggan, sehingga mereka bersedia datang kembali untuk membeli produk dan jasa yang 
ditawarkan.

c) Harus selalu memperhatikan apa yang menjadi harapan pelanggan dan melakukan hal-hal yang melebihi harapan pelanggan.

\section{Faktor yang berpengaruh terhadap kepuasan pelanggan}

Kotler dalam Parasuraman (2006) menjelaskan ada beberapa faktor yang berpengaruh terhadap kepuasan pelanggan yaitu:

a. Wujud fisik (tangible): semua barang yang dapat dilihat secara kasap mata, seperti sarana dan prasarana perusahaan dan bangunan fisik.

b. Kehandalan (reliability): karyawan selalu cepat dan akurat dalam menyelesaikan masalah nasabah.

c. Daya tanggap (responsiveness): meliputi kecepatan karyawan dalam menyelesaikan tugasnya seperti kedisiplinan dan kecekatan karyawan.

d. Jaminan (assurance): meliputi kepercayaan pelanggan kepada perusahaan, seperti perusahaan menepati janji dengan apa yang telah disepakati dengan pelanggan.

e. Kepedulian (emphaty): meliputi rasa ketulusan perusahaan dalam menjalankan amanahnya dari pelanggan. Contohnya, kepedulian karyawan terhadap kebutuhan dan keinginan pelanggan yang selalu dipenuhi dengan baik.

\section{Kerangka pemikiran teoritis}

Kerangka pemikiran teoritis dalam penelitian ini menerapkan dasar teoritis sebagaimana yang dinyatakan oleh Zeithaml, Berry, Parasuraman (2006). Berdasarkan teori yang dikemukakan di atas, maka pengembangan kerangka pikir dapat dilihat seperti dibawah ini: 


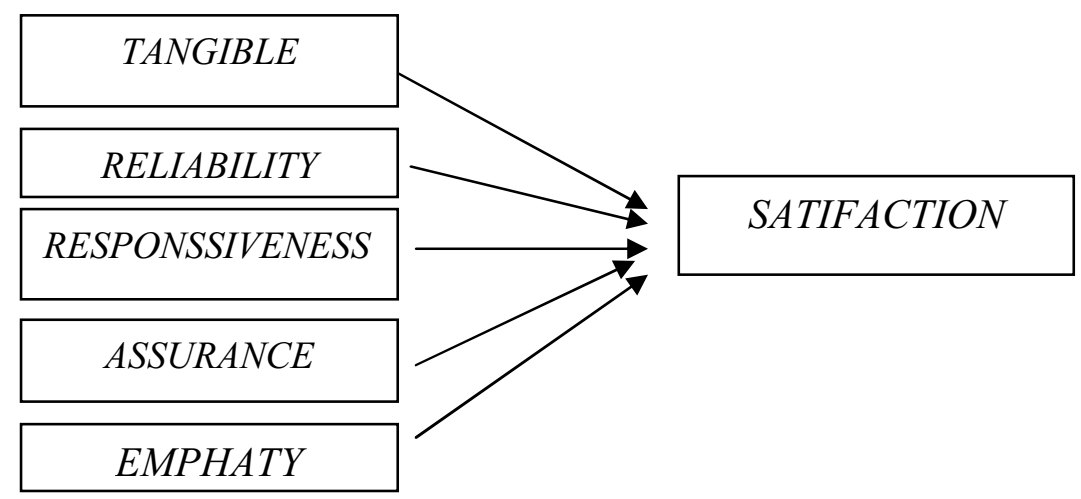

Gambar 1 Kerangka Pemikiran Teoritis

Sumber: Zeithaml, Berry, Parasuraman (2006)

\section{Hipotesis penelitian}

Tolak ukur wujud fisik dapat diketahui dari kepuasan pelanggan terhadap tersedianya sarana dan prasarana perusahaan yang memadai ruangan yang ber $A C$, sehingga nasabah merasa nyaman ketika bertransaksi. Beberapa penelitian mengenai pengaruh positif signifikan antara wujud fisik (tangible) terhadap kepuasan nasabah adalah Sumardiningsih et. al (2012), Sanistasya (2010) dan Soffan (2013). Oleh karena itu, hipotesis yang diajukan adalah:

$\mathrm{H}_{1 \mathrm{a}}$ : Tangible berpengaruh positif pada kepuasan tinggi nasabah.

$\mathrm{H}_{1 \mathrm{~b}}$ : Tangible berpengaruh positif pada kepuasan rendah nasabah.

Tolak ukur kehandalan (reliability) dapat diketahui dari kepuasan pelanggan terhadap pelayanan masalah secara teliti dan akurat, pelayanan yang cepat dan tepat, pelayanan sesuai dengan nomer antrean, produk yang ditawarkan mulai dari pembiayaan dan pendanaan, dan keterbukaan dalam bertransaksi. Beberapa penelitian mengenai pengaruh positif signifikan antara kehandalan (reliability) terhadap kepuasan nasabah pernah diteliti sebelumnya oleh Nasrul (2014), Sudarwati (2013) dan Sondakh (2014). Oleh karena itu, hipotesis yang diajukan adalah:

$\mathrm{H}_{2 \mathrm{a}}$ : Reliability berpengaruh positif pada kepuasan tinggi nasabah.

$\mathrm{H}_{2 \mathrm{~b}}$ : Reliability berpengaruh positif pada kepuasan rendah nasabah 
Tolok ukur daya tanggap dapat diketahui dari kepuasan pelanggan terhadap ketanggapan pelayanan karyawan perusahaan. Daya tanggap dapat diwujudkan dengan perilaku yang baik ketika terdapat komplain dari nasabah dan karyawan mampu mengatasinya dengan benar. Beberapa penelitian mengenai pengaruh positif signifikan antara daya tanggap (responsiviveness) terhadap kepuasan nasabah pernah diteliti sebelumnya oleh Guspul (2014), Agustin (2010) dan Yunanto (2010). Oleh karena itu, hipotesis yang diajukan adalah:

$\mathrm{H}_{3 \mathrm{a}}$ : Responsiveness berpengaruh positif pada kepuasan tinggi nasabah. $\mathrm{H}_{3 \mathrm{~b}}$ : Responsiveness berpengaruh positif pada kepuasan rendah nasabah.

Assurance dapat diketahui dari karyawan yang memiliki pengetahuan luas mengenai dunia perbankan syari'ah dan pengelolaan dana sesuai syari'at. Beberapa penelitian mengenai pengaruh positif signifikan antara jaminan (assurance) terhadap kepuasan nasabah pernah diteliti sebelumnya oleh Leksono (2013), Alida (2007) dan Anjar (2008). Oleh karena itu, hipotesis yang diajukan adalah:

$\mathrm{H}_{4 \mathrm{a}}$ : Assurance berpengaruh positif pada kepuasan tinggi nasabah.

$\mathrm{H}_{4 \mathrm{~b}}$ : Assurance berpengaruh positif pada kepuasan rendah nasabah.

Kepedulian (empathy) diwujudkan dengan kesiapan karyawan dalam memberikan informasi kepada nasabah, dan tercukupinya segala kebutuhan dan keinginan pelanggan secara terus-menerus. Beberapa penelitian mengenai pengaruh positif signifikan antara kepedulian (empathy) pada kepuasan nasabah pernah diteliti sebelumnya oleh Prasetyo (2011) dan Hayati (2011). Oleh karena itu, hipotesis yang diajukan adalah:

$\mathrm{H}_{5 \mathrm{a}}$ : Empathy berpengaruh pada kepuasan tinggi nasabah.

$\mathrm{H}_{5 \mathrm{~b}}$ : Empathy berpengaruh pada kepuasan rendah nasabah.

\section{Populasi dan sampel}

Populasi dalam penelitian ini adalah mahasiswa IAIN Salatiga Fakultas Ekonomi dan Bisnis Islam dengan jumlah 762 pada tahun 2015. Mahasiswa FEBI IAIN Salatiga dipilih karena mereka lebih memahami tentang dunia produk bank syari'ah dan nisbah bagi hasilnya. 
Sampel yang digunakan sebanyak 150 dengan menggunakan rumus Slovin untuk menentukan besarnya sampel. Penelitian ini menggunakan desain sampel nonprobabilitas, yang menggunakan metode sampling purposive (purposive or judgemental sampling) dengan kriteria responden adalah mahasiswa IAIN Salatiga Fakultas Ekonomi dan Bisnis Islam (FEBI) dan mempunyai rekening di Bank Syariah Mandiri.

\section{Metode Pengumpulan Data}

Data yang digunakan dalam penelitian ini adalah data primer dan data sekunder. Cara pengumpulan data dengan kuesioner yang menggunakan skala likert.

Definisi Konseptual dan Operasional Variabel

1. Variabel Independen (X)

a. Wujud Fisik (Tangible)

Menurut Irawan (2005: 58) wujud fisik merupakan sesuatu yang bisa dilihat, bisa dicium dan bisa diraba. Menurut Oktavi (2010) indikator wujud fisik meliputi fasilitas fisik seperti area parkir yang luas, ruangan yang nyaman, perlengkapan seperti tersedia formulir dan cara pengisiannya, pegawai yang rapi dan sarana komunikasi.

b. Kehandalan (Reliability)

Menurut Oktavi (2010) indikator kehandalan meliputi pelayanan masalah secara teliti dan akurat, pelayanan yang cepat dan tepat, pelayanan sesuai dengan nomer antrean, produk yang ditawarkan mulai dari pembiayaan dan pendanaan, dan keterbukaan dalam bertransaksi.

c. Daya Tanggap (Responsiveness)

Menurut Lupiyoadi (2001) daya tanggap merupakan kemauan untuk membantu dan memberikan pelayanan dengan penyampaian informasi yang jelas. Menurut Oktavi (2010) indikator daya tanggap meliputirespon yang baik dari karyawan kepada pelanggannya seperti satpam membukakan pintu ketika nasabah masuk ruangan, karyawan mampu mengatasi semua masalah pelanggan, dan pelayanan bagian 
back office yang baik.

d. Jaminan (Assurance)

Menurut Tjiptono (2007) jaminan merupakan upaya perlindungan yang disajikan untuk masyarakat bagi warganya terhadap resiko yang terjadi. Menurut Oktavi (2010) indikator jaminan meliputi pengetahuan karyawan yang luas mengenai dunia perbankan syari'ah dan produk-produk bank syari'ah.

e. Kepedulian (Empathy)

Menurut Bender (2009) kepedulian yaitu perhatian secara individual yang diberikan perusahaan kepada pelanggan. Menurut Oktavi (2010) indikator kepedulian meliputi rasa peduli perusahaan untuk selalu mencukupi kebutuhan dan keinginan pelanggan contohnya karyawan dapat berkomunikasi dengan baik, dan karyawan selalu siap dalam mengatasi masalah nasabah.

2. Variabel dependen

\section{Kepuasan Pelanggan (Satifaction)}

Menurut Oliver yang dikutip oleh Tjiptono dan Chandra (2011: 74) kepuasan merupakan suatu sikap yang diputuskan berdasarkan pengalaman yang didapatkan. Menurut Oktavi (2010) indikator kepuasan pelanggan dapat diukur ketika nasabah merasa puas dan nyaman dengan ruang yang tersedia, nasabah merasa puas dengan keramahan karyawan, nasabah merasa puas dengan kinerja karyawan ketika bertransaksi serta kebutuhan dan keinginan nasabah terpenuhi.

\section{Metode analisis}

Analisis data yang dilakukan adalah analisis regresi berganda dengan sebelumnya melakukan uji Realibilitas dan Uji Validitas serta uji asumsi klasik.

Persamaan regresi yang digunakan adalah : 


$$
\mathrm{Y}: \mathrm{a}+\mathrm{b} 1 \mathrm{X} 1+\mathrm{b} 2 \mathrm{X} 2+\mathrm{b} 3 \mathrm{X} 3+\mathrm{b} 4 \mathrm{X} 4+\mathrm{b} 5 \mathrm{Xb} 5+e
$$

Keterangan :

Y : Kepuasan nasabah

a : Konstanta

$\mathrm{X} 1$ : Variabel wujud fisik (tangible)

X2: Variabel kehandalan(reliability)

X3 : Variabel daya tanggap (responsiveness)

$\mathrm{X} 4$ : Variabel jaminan (assurance)

X5 : Variabel kepedulian (empathy)

e : Error (terdapat kesalahan)

\section{Karakteristik responden}

Berdasarkan tabel di bawah ini, dapat diketahui bahwa jenis kelamin mahasiswa IAIN Salatiga yang diambil sebagai responden terbanyak adalah mahasiswa perempuan yaitu sebanyak 94 mahasiswa atau $62,7 \%$ dibanding mahasiswa laki-laki hanya 56 mahasiswa atau 37,3\%.

Tabel 2

Karakteristik Responden

\begin{tabular}{lllc}
\hline No & \multicolumn{2}{c}{ Karakteristik Responden } & Jumlah \\
\hline \multirow{2}{*}{ Jenis Kelamin } & Laki-Laki & 56 \\
\cline { 3 - 4 } & & Perempuan & 94 \\
\hline \multirow{2}{*}{ Program Studi } & D3 PS & 32 \\
\cline { 3 - 4 } & & S1 PS & 118 \\
\hline \multirow{2}{*}{ Semester } & Tiga & 55 \\
\cline { 3 - 4 } & & Lima & 31 \\
\cline { 3 - 4 } & & Tujuh & 36 \\
\cline { 3 - 4 } & Sembilan & 28 \\
\hline \multirow{2}{*}{ Uang saku } & $<$ Rp. 400.000 & 62 \\
\cline { 3 - 4 } & & Rp. 400.000 - Rp. 800.000 & 60 \\
\cline { 3 - 4 } & & Rp. 800.000-Rp. 1.200.000 & 23 \\
\cline { 3 - 4 } & & Rp. 1.200.000- Rp. 1.600.000 & 3 \\
\cline { 3 - 4 } & & Rp. 1.600.000-Rp. 2.000.000 & 1 \\
\cline { 3 - 4 } & & $>$ Rp. 2000.000 & 1 \\
\hline
\end{tabular}


Berdasarkan Tabel 2 tersebut, responden terbanyak merupakan responden perempuan dengan jumlah 94 mahasiswa, berasal dari Program Studi S1-Perbankan Syariah sebanyak 118 mahasiswa atau 78,7\% dan mayoritas berada pada semester tiga yaitu 55 mahasiswa atau 36,7\%. Tabel 2 menunjukkan pula bahwa mayoritas uang saku mahasiswa adalah ${ }^{-} \mathrm{Rp}$. 400.000 yaitu 62 mahasiswa atau $41,3 \%$.

Hasil uji reliabilitas dan uji validitas yang dilakukan terhadap instrumen penelitian ini menunjukkan bahwa semua butir pertanyaan reliabel dan valid. Berdasarkan hasil pengujian asumsi klasik menunjukkan bahwa data dalam penelitian ini sudah memenuhi uji multikolinearitas, heterokedastisitas, autokorelasi, dan normalitas.

Berdasarkan hasil pengujian regresi berganda pada Tabel 3 menunjukkan bahwa secara parsial variabel reliability, responsiveness, dan empathy berpengaruh pada kepuasan nasabah tinggi dan rendah Bank Syariah Mandiri Cabang Salatiga. Hal ini ditunjukkan dengan nilai signifikansi sebesar $0,000<0,05$ sehingga hipotesis $\mathrm{H}_{2 \mathrm{a}}, \mathrm{H}_{2 \mathrm{~b}}, \mathrm{H}_{3 \mathrm{a}}, \mathrm{H}_{3 \mathrm{~b}}, \mathrm{H}_{5 \mathrm{a}}$ dan $\mathrm{H}_{5 \mathrm{~b}}$ didukung dalam penelitian ini. Berdasarkan pengujian tersebut dapat diketahui pula bahwa $\mathrm{H}_{1 \mathrm{a}}, \mathrm{H}_{1 \mathrm{~b}}, \mathrm{H}_{4 \mathrm{a}}$ dan $\mathrm{H}_{4 \mathrm{~b}}$ tidak didukung dalam penelitian ini karena nilai signifikansinya $>0,05$.

Berdasarkan hasil uji F menunjukkan bahwa secara bersama-sama variabel tangible, reliability, responsiveness, assurance, dan empathy berpengaruh pada kepuasan tinggi dan rendah nasabah Bank Syariah Mandiri Cabang Salatiga. $\mathrm{Hal}$ ini dapat dilihat dari nilai signifikansinya sebesar $0,000<0,05$.

Tabel 3

Hasil Regresi Berganda

\begin{tabular}{lcc}
\hline \multicolumn{1}{c}{ Variabel } & Koefisien & Signifikansi \\
\hline Konstanta & $-0,0127$ & \\
\hline Tangible & $-0,0630$ & 0,366 \\
\hline Reliability & 0,2830 & 0,543 \\
\hline Responsiveness & 0,7540 & $0,000^{* * *}$ \\
\hline Assurance & 0,0200 & $0,000^{* * *}$ \\
\hline Empathy & 3,6680 & 0,657 \\
\hline R Squared & 0,868 & $0,000^{* * *}$ \\
\hline Ftest & & \\
\hline
\end{tabular}


Analisis Pengaruh Kualitas Pelayanan terhadap Kepuasan Tinggi dan...

\begin{tabular}{lcl}
\hline & Kepuasan Tinggi & \\
\hline Konstanta & 0,089 & 0,606 \\
\hline Tangible & 0,083 & 0,277 \\
\hline Reliability & 0,273 & $0,000^{* * *}$ \\
\hline Responsiveness & 0,593 & $0,000^{* * *}$ \\
\hline Assurance & 0,018 & 0,641 \\
\hline Empathy & 0,542 & $0,000^{* * *}$ \\
\hline R Squared & 0,862 & \\
\hline Ftest & & $0,000^{* * *}$ \\
\hline
\end{tabular}

Sumber: Data Diolah

***) sig pada $1 \%$

Hasil regresi linear berganda menunjukkan bahwa wujud fisik (tangible) tidak berpengaruh pada kepuasan tinggi dan kepuasan rendah. Dimensi tangible ditingkatkan dengan cara memperhatikan penataan dan pengaturan ruang "front office", fasilitas yang dimiliki, peralatan yang dimiliki sesuai jasa yang diberikan, dan memperhatikan kerapian karyawan. Hasil ini mendukung penelitian yang dilakukan oleh Sumardiningsih et. al. (2012), Sanistasya (2010) dan Soffan (2013) menyatakan bahwa variabel wujud fisik (tangible) berpengaruh signifikan terhadap kepuasan nasabah karena fasilitas yang disediakan sepenuhnya digunakan oleh Bank untuk meningkatkan kualitas pelayanan.

Hasil regresi linear berganda pengaruh kehandalan (reliability) terhadap kepuasan menunjukkan bahwa kehandalan berpengaruh pada kepuasan tinggi dan kepuasan rendah. Dimensi kehandalan (reliability) ditingkatkan dengan cara menepati janji kepada nasabah, apabila mengadakan sebuah perjanjian, bersikap simpati untuk menolong para nasabah apabila nasabah memiliki masalah, pihak Bank Mandiri Syari'ah cabang Salatiga dapat diandalkan dan dipercaya dalam melayani nasabahnya, dan membuat catatan dengan benar dan akurat. Hasil ini mendukung penelitian yang dilakukan oleh oleh Nasrul (2014), Sudarwati (2013) dan Sondakh (2014) yang menyatakan bahwa variabel kehandalan (reliability) berpengaruh positif dan signifkan terhadap kepuasan nasabah dengan meningkatkan pelayanan dengan baik.

Hasil regresi linear berganda menunjukkan daya tanggap (responsiviness) berpengaruh pada kepuasan tinggi dan rendah. Dimensi 
daya tanggap (responsiviness) ditingkatkan dengan cara lebih meyakinkan nasabah dalam melaksanakan pekerjaannya, memberikan rasa nyaman, aman kepada nasabahnya, bersikap sopan, memberikan pengetahuan dan kemampuan yang cukup dalam bekerja. Hasil ini mendukung penelitian yang dilakukan oleh Sudarwati (2013) dan Nasrul (2014) dengan jumlah 100 responden bahwa variabel daya tanggap (responsiviness) berpengaruh sigifikan terhadap kepuasan nasabah.

Hasil regresi linear berganda pengaruh jaminan (assurance) terhadap kepuasan menunjukkan jaminan (assurance) tidak berpengaruh signifikan terhadap kepuasan tinggi dan kepuasan rendah. Dimensi jaminan dapat diwujudkan dengan janji-janji perusahaan yang telah ditepatinya dengan baik. Hasil ini mendukung penelitian yang dilakukan oleh Leksono (2013), Alida (2007) dan Anjar (2008) bahwa variabel jaminan (assurance) tidak berpengaruh sigifikan terhadap kepuasan nasabah.

Hasil regresi linear berganda menunjukkan bahwa kepedulian (empathy) berpengaruh terhadap kepuasan tinggi dan kepuasan rendah. Dimensi kepedulian (empathy) dapat diketahui dari rasa peduli perusahaan terhadap setiap pelanggan. Kepedulian dapat diwujudkan dengan tercukupinya segala kebutuhan dan keinginan pelanggan secara terusmenerus. Hasil ini tidak mendukung penelitian yang dilakukanoleh Prasetyo (2011) dan Hayati (2011) bahwa variabel kepedulian (empathy) berpengaruh positif dan signifkan terhadap kepuasan nasabah dengan memperhatikan kebutuhan dan keinginan nasabah.

\section{Penutup}

Berdasarkan pembahasan tersebut di atas, dapat disimpulkan bahwa:

1. Wujud fisik (tangible) tidak berpengaruh terhadap kepuasan tinggi dan rendah nasabah Bank Syariah Mandiri Cabang Salatiga.

2. Kehandalan (reliability) berpengaruh positif signifikan terhadap kepuasan tinggi dan rendah nasabah Bank Syariah Mandiri Cabang Salatiga.

3. Daya tanggap (responsiviness) berpengaruh positif signifikan terhadap kepuasan tinggi dan rendah nasabah Bank Syariah Mandiri Cabang Salatiga. 
4. Jaminan (assurance) tidak berpengaruh signifikan terhadap kepuasan tinggi dan rendah nasabah Bank Syariah Mandiri Cabang Salatiga.

5. Empathy berpengaruh positif signifikan terhadap kepuasan tinggi dan rendah nasabah Bank Syariah Mandiri Cabang Salatiga.

6. Saran untuk penelitian mendatang adalah menambah variabel-variabel independen yang dapat mempengaruhi kepuasan nasabah dan penelitian tidak hanya pada satu lembaga keuangan agar hasilnya dapat dibandingkan.

\section{Daftar Pustaka}

Abdullah. 2012. Kualitas Pelayanan dan Kepuasan Pelanggan. Jakarta: Penerbit Erlangga.

Agustin, Melly. 2010. "Pengaruh Kualitas Pelayanan terhadap Kepuasan pada Nasabah PT. Bank Niaga, Tbk (Kantor Cabang Kalimalang Bekasi)". Www.gunadarma.ac.id.

Alvianolita. 2015. "Pengaruh Kualitas Pelayanan terhadap Kepuasan Nasabah dan Loyalitas Nasabah Tabungan Britama Pada PT. Bank Rakyat Indonesia (Persero) Tbk Cabang Samarinda”. ejournal.adbisnis.fisip-unmul.ac.id. Fakultas Ilmu Sosial dan Ilmu Politik Mulawarman.

Ayu. 2014. "Pengaruh Kualitas Pelayanan terhadap Kepuasan dan Loyalitas Nasabah PT. BPR HOKI di Kabupaten Tabanan”. E-Jurnal Ekonomi dan Bisnis Universitas Udayana, 3.5 (2014) : 257-275.

Booklet, P. I. 2009. Pengukuran Perbankan Indonesia Edisi maret. Vol. 6 ISSN: 423: Jakarta .

Bender, Marie. 2009. Definisi Harapan dan Kepedulian. Jakarta: Penerbit Erlangga.

Guspul. 2014. "Pengaruh Kualitas Layanan Kepercayaan dan Kepuasan Klien (Studi Kasus Klien Kospin Layanan Cabang Wonosobo)”. Jurnal Riset Bisnis dan Manajemen, Vol.3, No.1, 2014:19-32.

Hayati, Nur. 2011. "Pengaruh Dimensi Kualitas Pelayanan terhadap Loyalitas Nasabah". Jurnal Sains Manajemen \& Akuntansi, Vol. III No. 2.

Hidayat, Rachmad. 2009. “Analisis Pelayanan terhadap Loyalitas Nasabah Bank Mandiri Medan”. Jurnal Manajemen dan Kewirausahaan, Vol.11. No. 1: 59-72.

Hurriyati, Rattih. 2010. Konsep Pengertian Jasa dan Kualitas Pelayanan. 
Bandung: Gentara Brilian.

Info, Bank. 2015. Majalah Info Pelayanan Bank Indonesia. Edisi 57. Jakarta. Irawan. 2005. Manajemen Pemasaran Modern. Yogyakarta: Liberty Kotler, Philip. 2002. Manajemen Pemasaran di Indonesia: Analisis, Perencanaan, Implementasi dan Pengendalian. Jakarta: Salemba Empat.

Leksono. 2013. Analisis Pengaruh Kualitas Pelayanan terhadap Kepuasan Nasabah pengguna Kartu BPD Card Bank Jateng Cabang Utama Semarang. Jurnal Economy, Vol.3, No.1, 2013:16-37.

Lupiyoadi, Hamdan. (2006). Manajemen Pemasaran Jasa. Edisi Kedua. Jakarta: Penerbit Salemba.

Nasrul. 2014. Pengaruh Kualitas Pelayanan terhadap Kepuasan Nasabah pada PT. BPR Pembangunan Nagari Kantor Pusat Lubuk Basung. Jurnal Riset Bisnis dan Manajemen, Vol. 3. No.1: 19-32.

Oktavi, Lalu Zulhendri. 2010. "Pengaruh Kualitas Pelayanan terhadap Kepuasan Nasabah Share-E di Yogyakarta (Studi Kasus pada Loket Share-E yang Berkedudukan di Kantor Pos Gondokusuman Yogyakarta)". Skripsi. UIN Sunan Kalijaga.

Palilita, Adila. 2007. "Konsep dan Penerapan Kualitas Pelayan terhadap Loyalitas Nasabah Bank Muammalat Palembang", Jurnal Manajemen dan Kewirausahaan, Vol. 9 No. 1, 2007: 73-81.

Parasuraman, Kotler. 2006. "Customer Service Quality". Journal of Marketing. Vol.65: 35-46.

Parasuraman, Valarie, A, Zeitham, Kotler and L.L Berry. 2006. "The Behavioural Consequences of Service Quality". Journal of Marketing, Vol. 60: 31-46.

Prasetyo. 2011."Analisis Pengaruh Kualitas Pelayanan terhadap kepuasan Nasabah Bank Rakyat Indonesia (Studi Kasus pada Bank rakyat Indonesia Unit Sampangan Kantor Cabang Semarang)". Jurnal Manajemen dan Kewirausahaan, Vol.11 No. 1: 59-72.

Sanistasya, Poppy Alvianolita. 2010. "Pengaruh Dimensi Kualitas Pelayanan terhadap Loyalitas Nasabah PT. Bank Muammalat Surakarta". Jurnal economy, Vol. 1. No. 2.

Soffan. 2013. "Kualitas Pelayanan Pengelolaan ATM dan Kepuasan Nasabah Bank BNI 1946 Pasuruan”. Jurnal Ilmu dan Riset Manajemen, Volume 1 Nomor 1: 134-148.

Sondakh, Conny. 2014. "Kualitas Layanan, Citra Merek Dan Pengaruhnya terhadap Kepuasan Nasabah dan Loyalitas Nasabah Tabungan (Studi Pada Nasabah Taplus BNI Cabang Manado". Jurnal Riset 
Bisnis dan Manajemen, Vol.3 No.1: 19-32.

Sudarwati. 2013. "Pengaruh Kualitas Pelayanan terhadap Kepuasan Nasabah SIMPEDES di Bank BRI Unit Baki". Jurnal Paradigma, Vol. 11. No. 02.

Sugiyono. 2004. Kualitas Pelayanan terhadap Kepuasan Nasabah. Jakarta : Penerbit Erlangga.

Sumardiningsih, Sri, Wawan, Endarwati, Arif, dan Yulia. 2013. "Pengaruh Dimensi Banking Service Quality (BSQ) terhadap Kepuasan Nasabah Bank". Jurnal Economia, Volume 8. Nomor 2.

Tjiptono, Chandra. 2011. Service, Quality dan Satifaction, Yogyakarta: Penerbit Abadi.

Yunanto. 2010. "Pengaruh Dimensi Kualitas Pelayanan terhadap Loyalitas Nasabah PT. Bank Danamon Surakarta dengan Nasabah Sebagai Variabel Pemediasi”. Thesis.Universitas Sebelas Maret Surakarta.

Zeithaml, Valarie. A and Bitner M.J. 2000. "Service Quality, Profitability, and the Economic Worth of Customers : What we know and What we need to Learn". Journal of The Academy of Marketing Sciences, Vol 28 (1): 67-85. 